\title{
PERLINDUNGAN HUKUM TERHADAP ANAK SEBAGAI KORBAN TINDAK PIDANA KESUSILAAN DALAM HUKUM PIDANA POSITIF SAAT INI
}

\author{
Sri Endah Wahyuningsih \\ Dosen Fakultas Hukum UNISSULA \\ Email: sriendahw@yahoo.com
}

\begin{abstract}
Problems of sexual offenses against children arising from the enforcement of the criminal law has not been oriented to the protection of victims, especially justice, but rather on the application of penalties on the offender. As a result, not make people afraid of committing a crime of morality, even more perpetrators of rape and sexual abuse against children ... the problem in this research is how the provisions of the legal protection of children as victims of sexual offenses under criminal law are positive today.

Legal protection of child victims of crime in the criminal law of chastity positive current on Article 287, 290, 292, 293, 294 and 295 of the Criminal Code and Article 81 and 82 of the Act. No. 23/2002, as amended. Act. No. 35 of 2014 as amended by Government Regulation No. 1 I 2016 on the amendment of the Law No. 23/2002 on Child Protection, and when the victims are included in the scope of the household, then apply the provisions of Articles 46 and 47 of the Law. No. 23/2004 on the Elimination of Domestic Violence, and Law No. 31/2014 on Witness and Victim Protection. weakness that emerged in the Act. No. 31/2014 is the absence of a provision governing the sanctions when players do not give restitution to the victims.
\end{abstract}

Keywords: Legal Protection, Children, Crime Morality

\begin{abstract}
Abstrak
Problematika tindak pidana asusila terhadap anak timbul karena penegakan hukum pidana selama ini belum berorientasi pada nilai keadilan terutama perlindungan korban, tetapi lebih pada penerapan hukuman pada pelaku. Akibatnya tidak membuat orang-orang takut melakukan tindak pidana kesusilaan, bahkan semakin banyak pelaku tindak pidana perkosaan dan pencabulan terhadap anak.. masalah dalam penelitian ini adalah bagaimana ketentuan perlindungan hukum terhadap anak sebagai korban tindak pidana asusila menurut hukum pidana positif saat ini.

Perlindungan hukum terhadap anak korban tindak pidana kesusilaan dalam hukum pidana positif saat ini terdapat pada Pasal 287, 290, 292, 293, 294 dan 295 KUHP dan Pasal 81 dan 82, UU. No. 23/ 2002 jo. UU. No. 35 Tahun 2014 jo Perpu No.1/ 2016 tentang Perubahan kedua atas UU No. 23/2002 tentang Perlindungan Anak, dan apabila korban termasuk dalam lingkup rumah tangga, maka berlaku juga ketentuan Pasal 46 dan 47 UU. No. 23/2004 tentang Penghapusan KDRT, serta UU No. 31/2014 tentang Perlindungan Saksi dan Korban. kelemahan yang muncul pada UU. No. 31/2014 adalah belum adanya suatu ketentuan yang mengatur sanksi apabila pelaku tidak memberi restitusi bagi korban.
\end{abstract}

Kata Kunci: Perlindungan Hukum, Anak, Tindak Pidana Kesusilaan.

\section{A. Latar belakang}

Meningkatnya jumlah kasus asusila baik itu kekerasan seksual ataupun pencabulan terhadap anak di dalam masyarakat mencerminkan lemahnya penegakan hukum di Indonesia selama ini. Kasus kekerasan seksual terhadap anak menimbulkan keresahan di dalam masyarakat tidak hanya para orang tua yang mempunyai anak gadis, tetapi juga orang tua yang mempunyai anak laki-laki.Anak yang menjadi korban perbuatan 
perkosaan ataupun pencabulan sering mengalami trauma berkepanjangan akibat kejadian tersebut. Kebanyakan mereka tidak dapat melupakan peristiwa buruk yang mereka alami.

Problematika berkenaan dengan tindak pidana asusila terhadap anak timbul karena hukuman penjara yang diberikan kepada pelaku tidak membuat orang-orang takut melakukan hal tersebut, malah semakin banyak pelaku tindak pidana perkosaan dan pencabulan terhadap anak. Walaupun telah banyak juga perundang-undangan yang mengancam pelaku tindak pidana asusila terhadap anak dengan ancaman pidana yang berat, tetapi tetap saja tindak pidana ini terjadi. Oleh karena itu dilakukan penelitian mengenai bagaimana perlindungan hukum terhadap anak sebagai korban tindak pidana kesusilaan menurut hukum pidana positif saat ini.

\section{B. Pembahasan}

Pelecehan seksual terhadap anak adalah suatu bentuk penyiksaan anak di mana orang dewasa atau remaja yang lebih tua menggunakan anak untuk rangsangan seksual. Bentuk pelecehan seksual anak termasuk meminta atau menekan seorang anak untuk melakukan aktivitas seksual (terlepas dari hasilnya), memberikan paparan yang tidak senonoh dari alat kelamin untuk anak, menampilkan pornografi untuk anak, melakukan hubungan seksual terhadap anak-anak, kontak fisik dengan alat kelamin anak (kecuali dalam konteks non-seksual tertentu seperti pemeriksaan medis), melihat alat kelamin anak tanpa kontak fisik (kecuali dalam konteks non-seksual seperti pemeriksaan medis), atau menggunakan anak untuk memproduksi pornografi anak. ${ }^{1}$

Perlindungan hukum bagi anak korban kejahatan kesusilaan dapat mencakup bentuk perlindungan yang bersifat abstrak (tidak langsung) maupun yang konkret (langsung). Perlindungan yang abstrak pada dasarnya merupakan bentuk perlindungan yang hanya bisa dinikmati atau dirasakan secara emosional (psikis), seperti rasa puas (kepuasan). Sementara itu, perlindungan yang kongkret pada dasarnya merupakan bentuk perlindungan yang dapat

1 Pelecehan Seksual terhadap Anak, dalam ww.wikipediaindonesia.com, diakses tanggal 3 November 2014 dinikmati secara nyata, seperti pemberian yang berupa atau bersifat materii maupun nonmateri. Pemberian yang bersifat materi dapat berupa pemberian kompensasi atau restitusi, pembebeasan beaya hidup atau pendidikan. Pemberian perlindungan yang bersifat nonmateri dapat berupa pembebasan dari ancaman, dari pemberitaan yang merendahkan martabat kemanusiaan.

Perlindungan hukum bagi anak korban kejahatan seksual dalam bentuk abstrak antara lain diatur dalam KUHP. Perumusan tindak pidana kesusilaan dalam KUHP yang dapat digunakan sebagai dasar untuk menjerat pelaku baik perbuatan persetubuhan atau pencabulan diatur dalam Bab XIV Pasal 287, Pasal 289, Pasal 290, Pasal 292, Pasal 293, Pasal 294, Pasal 295, dan Pasal 296 KUHP. Terhadap pelaku diancam dengan pidana penjara antara 9 bulan sampai dengan 7 tahun dan pidana denda antara Rp.15.000.00 (lima belas ribu rupiah).

Selain itu juga terdapat dalam ketentuan Pasal 81 Undang-Undang Nomor 23 Tahun 2002 tentang Perlindungan Anak, dinyatakan bahwa:

(1) Setiap orang yang dengan sengaja melakukan kekerasan atau ancaman kekerasan memaksa anak melakukan persetubuhan dengannya atau dengan orang lain, dipidana dengan pidana penjara paling lama 15 (lima belas) tahun dan paling singkat 3 (tiga) tahun dan denda paling banyak Rp 300.000.000,00 (tiga ratus juta rupiah) dan paling sedikit $R p$ $60.000 .000,00$ (enam puluh juta rupiah).

(2) Ketentuan pidana sebagaimana dimaksud dalam ayat (1) berlaku pula bagi setiap orang yang dengan sengaja melakukan tipu muslihat, serangkaian kebohongan, atau membujuk anak melakukan persetubuhan dengannya atau dengan orang lain.

Sedangkan menurut ketentuan Pasal 81 Undang-Undang Nomor 35 Tahun 2014 tentang Perubahan Atas Undang-Undang Nomor 23 Tahun 2002 tentang Perlindungan Anak, dinyatakan bahwa:

(1) Setiap orang yang melangggar ketentuan sebagaimana dimaksud dalam Pasal 76D dipidana dengan pidana penjara 
paling singkat 5 (lima) tahun dan paling lama 15 (lima belas) tahun dan denda paling banyak Rp5.000.000.000,00 (lima miliar rupiah).

(2) Ketentuan pidana sebagaimana dimaksud pada ayat (1) berlaku pula bagi Setiap Orang yang dengan sengaja melakukan tipu muslihat, serangkaian kebohongan, atau membujuk Anak melakukan persetubuhan dengannya atau dengan orang lain.

(3) Dalam hal tindak pidana sebagaimana dimaksud pada ayat (1) dilakukan oleh Orang Tua, Wali, pengasuh Anak, pendidik, atau tenaga kependidikan, maka pidananya ditambah $1 / 3$ (sepertiga) dari ancaman pidana sebagaimana dimaksud pada ayat (1).

Selain itu perlindungan terhadap anak juga menjadi komitmen pemerintah yaitu dengan dikeluarkannya Perpu No. 1 tahun 2016 tentang Perubahan kedua UU No. 2 tahun 2002 tentang Perlindungan Anak. Dalam Perpu antara lain diatur mengenai pidana pemberatan, pidana tambahan, dan tindakan lain bagi pelaku. Pemberatan pidana berupa tambahan pidana sepertiga dari ancaman penjara paling singkat 10 tahun dan paling lama 20 tahun. Selain itu, ancaman hukuman seumur hidup dan hukuman mati pun masuk ke pemberatan pidana. Sedangkan untuk tambahan pidana alternatif yang diatur ialah pengumuman identitas pelaku, kebiri kimia, dan pemasangan alat deteksi elektronik.

Berdasarkan ketentuan di atas, selain pidana penjara terdapat juga terdapat pidana denda bagi pelaku tindak pidana kejahatan seksual terhadap anak. Pidana denda yang tercantum dalam Undang-Undang Perlindungan Anak tersebut sebenarnya cukup ironis, karena pidana denda tidak mengakomodir kepentingan anak selaku korban tetapi hanya mengakomodir kepentingan negara, yaitu sebagai pemasukan kepada kas negara yang mana hal tersebut tidak memberikan manfaat apapun bagi anak selaku korban kejahatan seksual.

Pemberian perlindungan terhadap anak korban kejahatan seksual, khususnya yang berupa pemenuhan ganti kerugian, baik melalui pemberian kompensasi dan/atau restitusi seharusnya memperoleh perhatian dari pembuat kebijakan. Mengenai kompensasi dan restitusi, Stephen Schafer, ${ }^{2}$ dalam bukunya "The Victim and His Criminal", mengemukakan 5 (lima) sistem pemberian kompensasi dan restitusi kepada korban kejahatan, yaitu: (1) ganti rugi yang bersifat perdata, diberikan melalui proses hukum perdata, terpisah dengan proses hukum pidana; (2) kompensasi yang bersifat keperdataan, diberikan melalui proses pidana; (3) restitusi yang bersifat perdata dan bercampur dengan sifat pidana, diberikan melalui proses pidana; (4) kompensasi yang bersifat perdata, diberikan melalui proses pidana dan didukung oleh sumbersumber penghasilan negara; (5) kompensasi yang bersifat netral diberikan melalui prosedur khusus.

Berdasarkan hal tersebut, sebenarnya pidana denda tidak perlu dimasukkan dalam Undang-Undang Perlindungan Anak. Adapun yang seharusnya dimasukkan dalam Undang-Undang Perlindungan Anak adalah sesuatu hal yang dapat mengakomodir kepentingan anak selaku korban kejahatan seksual, yaitu pemberlakuan restitusi. Dalam perkembangan selanjutnya muncul bentuk lain yaitu masyarakat harus diberi kesempatan untuk memintakan pertanggungjawaban dari si pembuat yang telah mengganggu ketentraman masyarakat dan untuk menghindari kemungkinan adanya kesewenang-wenangan bagi korban, diperlukan jalan hukum melalui ganti kerugian dari si pembuat untuk korban dan masyarakat untuk menutup akibat gangguan sosial dalam masyarakat. Peraturan Pemerintah No. 44 Tahun 2008 tentang Pemberian Kompensasi, Restitusi dan Bantuan kepada Saksi dan Korban didalam Pasal 20 sampai dengan Pasal 33 telah mengatur mengenai pemberian ganti kerugian (restitusi) dari pelaku tindak pidana kepada korban tindak pidananya.

Selain restitusi, korban tindak pidana dalam hal ini anak yang sekaligus menjadi saksi tindak pidana yang dialaminya, juga mendapat bantuan rehabilitasi sebagaimana diatur dalam Pasal 6 Undang-undang Nomor 31 Tahun 2014 tentang Perubahan Atas Undang-Undang No. 13 Tahun 2006 tentang Perlindungan Saksi dan Korban, yaitu:

2 Stephen Schafer, 1968, The Victim and His Criminal, Randam House, New York, hlm. 105. 
(1) Korban pelanggaran hak asasi manusia yang berat, Korban tindak pidana terorisme, Korban tindak pidana perdagangan orang, Korban tindak pidana penyiksaan, Korban tindak pidana kekerasan seksual, dan Korban penganiayaan berat, selain berhak sebagaimana dimaksud dalam Pasal 5 , juga berhak mendapatkan:

a. bantuan medis; dan

b. bantuan rehabilitasi psikososial dan psikologis.

(2) Bantuan sebagaimana dimaksud pada ayat (1) diberikan berdasarkan Keputusan LPSK

Selain ancaman hukuman untuk pelaku, juga diatur mengenai perlindungan hukum bagi anak korban kejahatan kesusilaan, yaitu UU. No. 35 Tahun 2014 tentang Perubahan Atas Undang-undang Nomor 23 tahun 2002 tentang Perlindungan Anak, yaitu Pasal 69A, bahwa Perlindungan Khusus bagi anak korban kejahatan seksual dilakukan melalui upaya:

1. edukasi tentang kesehatan reproduksi, nilai agama, dan nilai kesusilaan;

2. rehabilitasi sosial;

3. pendampingan psikososial pada saat pengobatan sampai pemulihan; dan

4. pemberian perlindungan dan pendampingan pada setiap tingkat pemeriksaan mulai dari penyidikan, penuntutan, sampai dengan pemeriksaan di sidang pengadilan.

Perlindungan saksi dan/ atau korban juga diatur dalam Pasal 5 Undang-undang Nomor 31 Tahun 2014 tentang Perlindungan Saksi dan Korban yang merupakan hak dari saksi dan/ atau korban yaitu:

1. memperoleh perlindungan atas keamanan pribadi, Keluarga, dan harta bendanya, serta bebas dari Ancaman yang berkenaan dengan kesaksian yang akan, sedang, atau telah diberikannya;

2. ikut serta dalam proses memilih dan menentukan bentuk perlindungan dan dukungan keamanan;

3. memberikan keterangan tanpa tekanan;

4. mendapat penerjemah;

5. bebas dari pertanyaan yang menjerat;
6. mendapat informasi mengenai perkembangan kasus;

7. mendapat informasi mengenai putusan pengadilan;

8. mendapat informasi dalam hal terpidana dibebaskan;

9. dirahasiakan identitasnya;

10. mendapat identitas baru;

11. mendapat tempat kediaman sementara;

12. mendapat tempat kediaman baru;

13. memperoleh penggantian biaya transportasi sesuai dengan kebutuhan;

14. mendapat nasihat hukum;

15. memperoleh bantuan biaya hidup sementara sampai batas waktu Perlindungan berakhir; dan/atau

16. mendapat pendampingan.

Anak korban tindak pidana asusila mendapatkan perlindungan berupa hak untuk mendapatkan restitusi. Ketentuan mengenai tata cara pemberian restitusi diatur dalam Pasal 7A dan 7B Undang-Undang No. 31 Tahun 2014 tentang Perubahan atas undang-undang No. 13 Tahun 2006 tentang Perlindungan Saksi dan Korban, yaitu:

\section{Pasal 7A}

(1) Korban tindak pidana berhak memperoleh Restitusi berupa:

a. ganti kerugian atas kehilangan kekayaan atau penghasilan;

b. ganti kerugian yang ditimbulkan akibat penderitaan yang berkaitan langsung sebagai akibat tindak pidana; dan/atau

c. penggantian biaya perawatan medis dan/atau psikologis.

(2) Tindak pidana sebagaimana dimaksud pada ayat (1) ditetapkan dengan Keputusan LPSK.

(3) Pengajuan permohonan Restitusi dapat dilakukan sebelum atau setelah putusan pengadilan yang telah memperoleh kekuatan hukum tetap melalui LPSK.

(4) Dalam hal permohonan Restitusi diajukan sebelum putusan pengadilan yang telah memperoleh kekuatan hukum tetap, LPSK dapat mengajukan Restitusi kepada penuntut umum untuk dimuat dalam tuntutannya. 
(5) Dalam hal permohonan Restitusi diajukan setelah putusan pengadilan yang telah memperoleh kekuatan hukum tetap, LPSK dapat mengajukan Restitusi kepada pengadilan untuk mendapat penetapan.

(6) Dalam hal Korban tindak pidana meninggal dunia, Restitusi diberikan kepada Keluarga Korban yang merupakan ahli waris Korban.

\section{Pasal 7B}

Ketentuan lebih lanjut mengenai tata cara permohonan dan pemberian Kompensasi dan Restitusi sebagaimana dimaksud dalam Pasal 7 dan Pasal 7A diatur dengan Peraturan Pemerintah.

Menurut Pasal 7B di atas, pemerintah harus segera membuat peraturan pemerintah sebagai pelaksanaan dari ketentuan Pasal 7 dan 7A di atas. Sementara itu, pelaksanaan ketentuan pemberian kompensasi dan restitusi masih dapat mengacu kepada Peraturan Pemerintah No. 44 Tahun 2008 tentang Pemberian Kompensasi, Restitusi dan Bantuan Kepada Saksi dan Korban selama tidak bertentangan dengan ketentuan dalam Undang-Undang No. 31 Tahun 2014 Perubahan atas undang-undang No. 13 Tahun 2006 tentang Perlindungan Saksi dan Korban.

Tata cara permohonan dan pemberian restitusi sebagaimana diatur dalam Peraturan Pemerintah No. 44 Tahun 2008 Pemberian Kompensasi, Restitusi dan Bantuan Kepada Saksi dan Korban termuat dalam pasal-pasal sebagai berikut:

\section{Pasal 20}

(1) Korban tindak pidana berhak memperoleh Restitusi.

(2) Permohonan untuk memperoleh Restitusi sebagaimana dimaksud pada ayat (1) diajukan oleh Korban, Keluarga, atau kuasanya dengan surat kuasa khusus.

(3) Permohonan untuk memperoleh Restitusi sebagaimana dimaksud pada ayat (2) diajukan secara tertulis dalam bahasa Indonesia di atas kertas bermeterai cukup kepada pengadilanmelalui LPSK.

\section{Pasal 21}

Pengajuan permohonan Restitusi dapat dilakukan sebelum atau setelah pelaku dinyatakan bersalah berdasarkan putusan pengadilan yang telah memperoleh kekuatan hukum tetap.

\section{Pasal 22}

(1) Permohonan Restitusi sebagaimana dimaksud dalam Pasal 20 memuat sekurang kurangnya:

a. identitas pemohon;

b. uraian tentang tindak pidana;

c. identitas pelaku tindak pidana;

d. uraian kerugian yang nyata-nyata diderita; dan

e. bentuk Restitusi yang diminta.

(2) Permohonan Restitusi sebagaimana dimaksud pada ayat (1) harus dilampiri:

a. fotokopi identitas Korban yang disahkan oleh pejabat yang berwenang;

b. bukti kerugian yang nyata-nyata diderita oleh Korban atau Keluarga yang dibuat atau disahkan oleh pejabat yang berwenang;

c. bukti biaya yang dikeluarkan selama perawatan dan/atau pengobatan yang disahkan oleh instansi atau pihak yangmelakukan perawatan atau pengobatan;

d. fotokopi surat kematian dalam hal Korbanmeninggal dunia;

e. surat keterangan dari Kepolisian Negara Republik Indonesia yang menunjukkan pemohon sebagai Korban tindak pidana;

f. surat keterangan hubungan Keluarga, apabila permohonan diajukan oleh Keluarga; dan

g. surat kuasa khusus, apabila permohonan Restitusi diajukan oleh kuasa Korban atau kuasa Keluarga.

(3) Apabila permohonan Restitusi sebagaimana dimaksud pada ayat (1) perkaranya telah diputus pengadilan dan telah memperoleh kekuatan hukum tetap, permohonan Restitusi harus dilampiri kutipan putusan pengadilan tersebut. 


\section{Pasal 28}

(1) Dalam hal permohonan Restitusi diajukan berdasarkan putusan pengadilan yang telah memperoleh kekuatan hukum tetap dan pelaku tindak pidana dinyatakan bersalah, LPSK menyampaikan permohonan tersebut beserta keputusan dan pertimbangannya sebagaimana dimaksud dalam Pasal 27 kepada pengadilan yang berwenang.

(2) Dalam hal permohonan Restitusi diajukan sebelum tuntutan dibacakan, LPSK menyampaikan permohonan tersebut beserta keputusan dan pertimbangannya kepada penuntut umum.

(3) Penuntut umum sebagaimana dimaksud pada ayat (2) dalam tuntutannya mencantumkan permohonan Restitusi beserta Keputusan LPSK dan pertimbangannya.

(4) Salinan surat pengantar penyampaian berkas permohonan dan pertimbangan sebagaimana dimaksud pada ayat (1) dan ayat (2), disampaikan kepada Korban, Keluarga atau kuasanya, dan kepada pelaku tindak pidana dan/atau pihak ketiga.

\section{Pasal 29}

(1) Dalam hal LPSK mengajukan permohonan Restitusi sebagaimana dimaksud dalamPasal 28 ayat (1), pengadilan memeriksa dan menetapkan permohonan Restitusi dalam jangka waktu paling lambat 30 (tiga puluh) hari terhitung sejak tanggal permohonanditerima.

(2) Penetapan pengadilan sebagaimana dimaksud pada ayat (1) disampaikan kepada LPSKdalam jangka waktu paling lambat 7 (tujuh) hari terhitung sejak tanggal penetapan.

(3) LPSK menyampaikan salinan penetapan pengadilan sebagaimana dimaksud pada ayat (2) kepada Korban, Keluarga, atau kuasanya dan kepada pelaku tindak pidana dan/ataupihak ketiga dalam jangka waktu paling lambat 7 (tujuh) hari terhitung sejak tanggalmenerima penetapan.
Pasal 30

(1) Dalam hal LPSK mengajukan permohonan Restitusi sebagaimana dimaksud dalam Pasal 28 ayat (2), putusan pengadilan disampaikan kepada LPSK dalam jangka waktu paling lambat 7 (tujuh) hari terhitung sejak tanggal putusan.

(2) LPSK menyampaikan salinan putusan pengadilan sebagaimana dimaksud pada ayat (1) kepada Korban, Keluarga, atau kuasanya dan kepada pelaku tindak pidana dan/atau pihak ketiga dalam jangka waktu paling lambat 7 (tujuh) hari terhitung sejak tanggal menerima putusan.

\section{Pasal 31}

(1) Pelaku tindak pidana dan/atau pihak ketiga melaksanakan penetapan atau putusan pengadilan sebagaimana dimaksud dalam Pasal 29 dan Pasal 30 dalam jangka waktu paling lambat 30 (tiga puluh) hari terhitung sejak tanggal salinan penetapan pengadilan diterima.

(2) Pelaku tindak pidana dan/atau pihak ketiga melaporkan pelaksanaan Restitusi kepada pengadilan dan LPSK.

(3) LPSK membuat berita acara pelaksanaan penetapan pengadilan sebagaimana dimaksud pada ayat (1).

(4) Pengadilan mengumumkan pelaksanaan Restitusi pada papan pengumuman pengadilan.

\section{Pasal 32}

(1) Dalam hal pelaksanaan pemberian Restitusi kepada Korban melampaui jangka waktu 30 (tiga puluh) hari sebagaimana dimaksud dalam Pasal 31 ayat (1), Korban, Keluarga, atau kuasanya melaporkan hal tersebut kepada Pengadilan yang menetapkan permohonan Restitusi dan LPSK.

(2) Pengadilan sebagaimana dimaksud pada ayat (1) segera memerintahkan kepada pelaku tindak pidana dan/atau pihak ketiga untuk melaksanakan pemberian Restitusi, dalam jangka waktu paling lambat 14 (empat belas) hari terhitung sejak tanggal perintah diterima. 


\section{Pasal 33}

Dalam hal pemberian Restitusi dilakukan secara bertahap, setiap tahapan pelaksanaan atau keterlambatan pelaksanaan harus dilaporkan Korban, Keluarga atau kuasanya kepada pengadilan yang menetapkan atau memutuskan permohonan Restitusi.

Selanjutnya syarat-syarat dan tata cara pemberian perlindungan dan bantuan saksi dan/ atau korban dalam Undang-Undang No. 31 Tahun 2014 Perubahan atas undang-undang No. 13 Tahun 2006 tentang Perlindungan Saksi dan Korban diatur pada pasal-pasal sebagai berikut: Pasal 28

(1) Perlindungan LPSK terhadap Saksi dan/atau Korban diberikan dengan syarat sebagai berikut:

a. sifat pentingnya keterangan Saksi dan/atau Korban;

b. tingkat Ancaman yang membahayakan Saksi dan/atau Korban;

c. hasil analisis tim medis atau psikolog terhadap Saksi dan/atau Korban; dan

d. rekam jejak tindak pidana yang pernah dilakukan oleh Saksi dan/ atau Korban.

Adapun kebijakan hukum pidana dalam RUU KUHP Februari 2015, pasal-pasal terkait dengan delik-delik atau rumusan tindak pidana yang tersebar di banyak undang-undang di luar KUHP telah coba untuk ditarik dan disatukan kembali. Khususnya terkait dengan delik yang dapat digunakan untuk menjerat pelaku tindak pidana asusila terhadap anak, yaitu dalam Bab XVI tentang Tindak Pidana Kesusilaan pada bagian keempat tentang Zina dan Perbuatan Cabul dan bagian kelima tentang Tindak Pidana Perkosaan dan Perbuatan Cabul yaitu Pasal 484, Pasal 487, pasal 488, Pasal 490, Pasal 491, Pasal 492, Pasal 493, Pasal 494, Pasal 495, Pasal 497. Sistem perumusan jumlah/lamanya pidana (strafmaat) tindak pidana asusila RUU KUHP Tahun 2015 adalah sistem minimum khusus dan maksimum khusus, yaitu:

1) Minimum khusus untuk pidana penjara berkisar antara 1 tahun sampai 3 tahun;

2) Maksimum khusus untuk pidana penjara berkisar antara 7 tahun sampai dengan 15 tahun;
3) Minimum khusus untuk pidana denda adalah kategori IV;

4) Maksimum khusus untuk pidana denda adalah kategori VI.

Jumlah Pidana denda, khususnya bagi korporasi dengan maksimum berkisar kategori IV sampai kategori VI, yaitu antara Rp. 300.000.000,sampai dengan Rp 12.000.000.000,- hendaknya dapat dikaji kembali untuk batas minimumnya, karena terus meningkatnya keuntungan yang diperoleh korporasi dalam penjualan anak untuk tujuan seks saat ini, khususnya pada jaringan penjualan dan penyediaan pasokan anak untuk tujuan seks.

\section{PENUTUP}

\section{KESIMPULAN}

Secara garis besar perlindungan terhadap anak korban tindak pidana asusila dapat dilakukan melalui 3 (tiga) cara yaitu:

a. menghukum pelaku tindak pidana asusila kepada anak dengan sanksi pidana yang berat sehingga tujuan pemidanaan dapat tercapai berdasarkan ketentuan UU.

b. dengan memberikan ganti kerugian kepada anak korban tindak pidana asusila dengan cara pemberian restitusi yang dibebankan kepada pelaku tindak pidana asusila tersebut.

c. dengan melakukan rehabilitasi terhadap anak korban tindak pidana asusila

Ketentuan-ketentuan yang mengatur tindak pidana asusila yang dilakukan kepada anak terdapat pada Pasal 287, 290, 292, 293, 294 dan 295 KUHP, Pasal 81 dan 82 UU.No. 23/ 2002 jo. UU. No. 35 Tahun 2014 jo Perpu No.1/2016 tentang perubahan kedua atas UU No.23/2003 tentang Perlindungan Anak dan apabila korban termasuk dalam lingkup rumah tangga, maka berlaku juga ketentuan Pasal 46 dan 47 UU. No. 23/2004 tentang Penghapusan KDRT, serta UU No.31/2014 tentang Perlindungan Saksi dan Korban

Selain ketentuan pidana atas kejahatan asusila terhadap anak, juga diatur tentang tata cara perlindungan anak korban tindak pidana asusila mengenai perlindungan pada saat terjadinya tindak pidana yaitu berkaitan dengan pemeriksaan korban sebagai saksi pada 
semua tingkat pemeriksaan di peradilan dari mulai penyidikan sampai dengan setelah putusan pengadilan, cara permohonan pembayaran ganti kerugian berupa restitusi dan bantuan rehabilitasi.

Ketentuan mengenai hal tersebut diatur dalam KUHAP dan juga peraturan perundangundangan lainnya terutama UU.No. 13 tahun 2006 sebagaimana diubah dengan UU No.31 Tahun 2014 ttg Perlindungan Saksi dan Korban. Kemudian mengenai tata cara pemberian restitusi dan bantuan rehabilitasi diatur tersendiri dalam PP No. 44 Tahun 2008 tentang Pemberian Kompensasi, Restitusi dan Bantuan Kepada Saksi dan Korban. Meskipun Undang-Undang No. 13 Tahun 2006 telah diubah dengan Undangundang Nomor 31 Tahun 2014, namun sebelum ada PP tentang pelaksanaan undang-undang yang baru, maka PP.No. 44/2008 masih tetap diterapkan sepanjang tidak bertentangan dengan undang-undang yang baru.

Persoalan yang muncul pada UU.No 31 Tahun 2014 tentang Perlindungan Saksi dan Korban adalah belum adanya suatu ketentuan yang mengatur sanksi apabila pelaku tidak memberi restitusi bagi korban. Kondisi ini akan memunculkan kejahatan lain yaitu pembiaran atau kelalaian yang disengaja.

Adapun dalam RUU KUHP Februari 2015, pasal-pasal terkait dengan delik-delik atau rumusan tindak pidana yang tersebar di banyak undangundang di luar KUHP telah coba untuk ditarik dan disatukan kembali (absorbsi). Khususnya terkait dengan delik yang dapat digunakan untuk menjerat pelaku tindak pidana asusila terhadap anak, yaitu dalam Bab XVI tentang Tindak Pidana Kesusilaan pada bagian keempat tentang Zina dan Perbuatan Cabul dan bagian kelima tentang Tindak Pidana Perkosaan dan Perbuatan Cabul yaitu Pasal 484, Pasal 487, pasal 488, Pasal 490, Pasal 491, Pasal 492, Pasal 493, Pasal 494, Pasal 495, Pasal 497 yang dapat digunakan untuk menjerat tindak pidana asusila terhadap anak di bawah umur.

\section{SARAN}

a.

b.

\section{DAFTAR PUSTAKA}

Abu Huraerah, 2006, Kekerasan Terhadap Anak, Nuansa, Bandung.

Abdul Wahid dan Muhammad Irfan, 2001, Perlindungan Terhadap Korban Kekerasan (advokasi atas hak asasi perempuan), Rafika Aditama, Bandung

Andi Hamzah, Perlindungan Hak-hak Azasi Manusia dalam Kitab Undang-undang Hukum Acara Pidana, Binacipta, Bandung, 1986

, Asas-asas hukum pidana, Pusat Studi Hukum Pidana Trisakti, 2005

Arif Gosita, Masalah Korban Kejahatan (kumpulan karangan), Akademika Pressindo, Jakarta,1993. , Bunga Rampai Viktimisasi, Bandung, PT. Eresco, 1995

, Relevansi Viktimologi Dengan Pelayanan Terhadap Para Korban Perkosaan (Beberapa

Catatan), (Jakarta, IND.HILL-CO, 1987

Barda Nawawi Arief, Masalah Penegakan Hukum Dan Kebijakan Penanggulangan Kejahatan, Bandung, Citra Aditya Bakti, 2001.

,Beberapa Aspek kebijakan Penegakan Dan Pengembangan Hukum Pidana, Bandung, Cipta Aditya Bakti, 1998.

,Bunga Rampai Kebijakan Hukum Pidana, Cet III, Bandung: PT. Citra Bakti, 2005

,Bunga Rampai Kebijakan Hukum Pidana (Perkembangan Penyusunan Konsep KUHP

Baru), Kencana Prenada Media Grup,Jakarta,2010

, Perlindungan Korban Kejahatan Dalam Proses Peradilan Pidana, Jurnal Hukum Pidana Dan Kriminologi, Vol. I/No.I/1998..

Cohen dalam Romli Atmasasmita, Masalah santunan Korban Kejahatan, BPHN, Jakarta, tanpa tahun, 
Israel Drapkin dan Emilio Viano, Victimology: A New Fokus, London, Lexington Books, D.E. Health and Company Massachusetts. 2005

J.E. Sahetapi, Viktimologi Sebuah Bunga Rampai, Jakarta, Pustaka Sinar Harapan, 1987. Mochtar Kusumaatmadja, Hubungan Antara Hukum Dengan Masyarakat : Landasan Pikiran, Pola dan Mekanisme Pelaksanaan Pembaharuan Hukum, BPHN-LIPI, Jakarta, 1976

Muladi, HAM dan Perspektif Sistem Peradilan Pidana, Refika Aditama, Bandung, 2005.

Muladi dan Barda Nawawi Arief, Bunga Rampai Hukum Pidana, Bandung, PT. Alumni, 1992. Moeljatno, Kitab Undang-Undang Hukum Pidana, Bumi Aksara, Jakarta, 2001

P.A.F Lamintang dan Theo Lamintang, Pembahasan KUHAP Menurut Ilmu Pengetahuan Hukum Pidana dan Yurisprudensi, Sinar Grafika, 2010

Ralp de Sola, Crime dictionar, New york : Facts on File Publication, 1998.

Sunaryati Hartono, Politik Hukum Menuju Satu Sistem Hukum Nasional, Alumni, Bandung, 1991

Soerjono Soekanto \& Sri Mamudji, Penelitian Hukum Normatif, Suatu Tinjauan Singkat, Rajawali, Jakarta, 1985.

Schafer dalam Separovic sebagimana dikutip dari Chaerudin dan Syarif Fadilah, Korban Kejahatan Dalam Perspektif Viktimologi dan Hukum Pidana Islam, Ghalia Press, Jakarta, Juli 2004.

Sudarto, Kapita Selekta Hukum Pidana, Alumni, Bandung, 1986

Soeharto, Perlindungan Hak Tersangka, Terdakwa, dan Korban Tindak Pidana terorisme (Dalam sistem Peradilan Pidana Indonesia), Refika Aditama, Bandung, 2007

Wadong, Hasan Maulana, Pengantar Advokasi dan Perlindungan Anak, Jakarta : Grasindo. 2000 